\title{
Manajemen Kepala Kantor Kementerian Agama Kota Jambi dalam Peningkatan Pelayanan Publik Bidang Pendidikan Agama Islam
}

\author{
M. Kholis \\ Kantor Wilayah Kementerian Agama Provinsi Jambi \\ E-mail: choles_m@yahoo.com \\ Jalaluddin \\ Pascasarjana UIN Sulthan Thaha Saifuddin Jambi \\ E-mail: jalaluddin@uinjambi.ac.id
}

\begin{abstract}
This study aims to examine the effort to improve public services in the field of Islamic education consists of curriculum and evaluation areas, educators and education personnel, facilities and infrastructure, student, institutional and information systems. This study uses qualitative descriptive methods through observation and indepth interviews with the Head of the Office of Religious Affairs Jambi City as key informant. Another informants are Head of Administration of sub-section, Section Head of the Madrasah Education, employees, and society. Furthermore, the technique of collecting data using interviews, observations and documentation study and data analysis. This research found that first, the Head Office of Religious Affairs Jambi City has a strategy to increase public services in the field of Islamic education, but the Head of the Office of Religious Affairs in Jambi City only involves some personnel clerks. Second, the implementation of public services in the field of Islamic education have not obtained good results, there are still dissatisfaction among Islamic teacher with the services provided by employees of Religious Office; Third, evaluation made by the Head Office of the Ministry of Religious Jambi in religious education public services have not been satisfactory, the gap between planning and implementation still happened in the field of Islamic education.
\end{abstract}

Keywords: Management; the Head of Religious Affairs Office; Public Services: Islamic Education.

Abstrak: Penelitian ini bertujuan untuk mengkaji upaya peningkatan pelayanan publik
bidang pendidikan agama Islam yang terdiri dari bidang kurikulum dan evaluasi, pendidik
dan tenaga kependidikan, sarana dan prasarana, kesiswaan, kelembagaan dan sistem
informasi. Penelitian ini menggunakan pendekatan penelitian kualitatif deskriptif, dengan
teknik pengambilan data melalui observasi dan wawancara. Pencarian informan dilakukan
secara purposive sampling, dengan informan kunci Kepala Kantor Kementerian Agama
Kota Jambi (KKKAKJ). Sedangkan Kasubbag TU, Kasi Pendidikan Madrasah, guru agama,
dan masyarakat sebagai informan lainnya. Penelitian ini menemukan bahwa pertama,
KKKAKJ sudah berupaya membuat perencanaan dalam meningkat pelayanan publik di
bidang Pendidikan Agama Islam, namun hanya melibatkan sebagian personel pegawai.
Kedua, KKKAKJ dalam meningkatkan pelayanan publik di bidang Pendidikan Agama Islam
belum memperoleh hasil yang maksimal, dibuktikan dengan adanya guru yang tidak puas
terhadap pelayanan yang diberikan. Ketiga, hasil evaluasi internal dari KKKAKJ sendiri
dalam meningkatkan pelayanan publik di bidang Pendidikan Agama Islam belum
memuaskan, masih terjadi ketidaksesuaian perencanaan dan pelaksanaan di lapangan. Kata-kata kunci: Manajemen; Kepala Kantor Kementerian Agama; Pelayanan Publik; dan Pendidikan Agama Islam. 


\section{Pendahuluan}

Administrasi kepegawaian merupakan bagian dari manajemen pemerintahan yang bertugas mengupayakan terbentuknya pegawai negeri sipil yang bersih, berwibawa dan sadar akan tanggung jawabnya sebagai abdi negara dan abdi masyarakat seperti ditegaskan dalam pasal 3 ayat (1) Undang-Undang Nomor 43 tahun 1999 tentang Pokok - Pokok Kepegawaian. Pegawai negeri memiliki peran sangat penting terhadap kelancaran penyelenggaraan pemerintahan dan pembangunan nasional yang berencana, terarah, terpadu dan dilaksanakan secara bertahap.

Seorang Kepala Kantor Kementerian Agama dalam menjalankan tugasnya dalam sebuah kegiatan manajemen dituntut untuk mempunyai suatu keterampilan, pengetahuan dan keahlian. Hal ini sesuai dengan hadits Rasullah SAW yang diriwayatkan oleh Bukhari sebagai berikut:

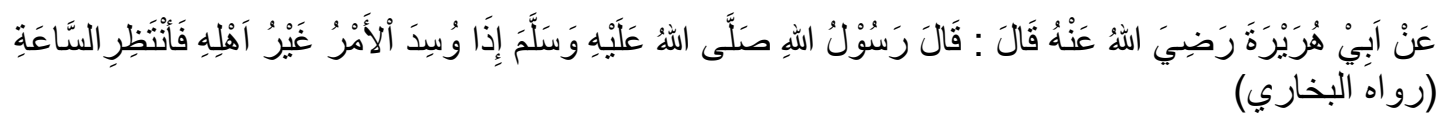

Artinya: Dari Abu Hurairah Ra. Berkata: Telah bersabda Rasulullah SAW "Jika sesuatu diserahkan kepada orang yang bukan ahlinya, maka tunggulah kehancurannya."1 (Riwayat Bukhari)

Kantor Kementerian Agama Kota Jambi merupakan barometer penggerak pembangunan umat beragama di Kota Jambi yang dipimpin oleh seorang Kakamenag yang seharusnya mampu memegang kendali organisasi/ kantor dan mampu membimbing setiap pegawainya agar mampu memberikan pelayanan yang maksimal kepada masyarakat. Citra birokrasi-birokrasi secara keseluruhan akan banyak ditentukan oleh manajemen kepemimpinan. Dengan adanya manajemen kepemimpinan kepala Kantor Kementerian Agama Kota Jambi diharapkan para masyarakat memperoleh pelayanan yang maksimal.

Pelayanan publik dalam perkembangannya timbul dari adanya kewajiban sebagai sebuah proses penyelenggaraan kegiatan pemerintahan baik yang bersifat individual maupun kelompok. Dalam pemberian pelayanan tidak boleh tercipta perlakuan yang berbeda, sehingga menimbulkan diskriminasi pelayanan bagi masyarakat. Selain itu, manajemen pelayanan perlu pula mendapat pembenahan melalui keterbukaan dan kemudahan prosedur, penetapan tarif yang jelas dan terjangkau, keprofesionalan aparatur dalam teknik pelayanan, dan tersedianya tempat pengaduan keluhan masyarakat (public complain), serta tersedianya sistem pengawasan terhadap pelaksanaan prosedur. ${ }^{2}$

Pelayanan publik yang diberikan oleh Kantor Kementerian Agama Kota Jambi adalah layanan bidang pendidikan, administrasi dan haji. Setelah melakukan grand tour di Kantor Kementerian Agama Kota Jambi, peneliti mendapati berbagai permasalahan manajemen kepala Kantor Kementerian Agama Kota Jambi dalam meningkatkan pelayanan bidang Pendidikan Agama Islam diantaranya adalah:(1)

${ }^{1} \mathrm{Al}$ Imam Al-Hafiz Abi Abdullah Muhammad Bin Ismail Al-Bukhori, Sohih Al-Bukhari (Kairo: Mussasah Al-Mukhtar, 2004), hlm. 27

${ }^{2}$ Adrian Sutedi, Hukum Perizinan dalam Sektor Pelayanan Publik, (Jakarta: Sinar Grafika, 2010), hlm. 3 . 
Belum maksimalnya manajemen yang dilakukan oleh Kepala Kantor Kementerian Agama Kota Jambi dalam peningkatan pelayanan publik, hal ini masih terdapat guru yang merasa belum puas pelayanan yang diberikan oleh pegawai Kementerian Agama Kota Jambi dalam bidang Pendidikan Agama Islam. ${ }^{3}$ (2) Belum bagusnya pelayanan yang diberikan Kepala Kantor Kementerian Agama Kota Jambi, karena masih terdapat guru yang melakukan urusan di bidang pendidikan tidak memperoleh pelayanan yang prima. ${ }^{4}$ (3) Kepala Kantor Kementerian Agama belum melakukan pengawasan yang baik kepada bawahannya dalam melaksanakan tugas untuk memberi pelayanan kepada guru, sehingga mengakibatkan masih terdapat guru yang tidak mau berurusan dengan kemenag Kota Jambi disebabkan pelayanan yang tidak bagus dan memakan waktu yang lama tidak sesuai dengan SOP dalam bidang Pendidikan Agama Islam.

Oleh sebab ditemukannya permasalahan tersebut, maka dengan menerapkan metodologi penelitian kualitiatif deskriptif dan menggunakan teknik wawancara, observasi dan teknik dokumentasi dalam pengumpulan data, penelitian ini ingin menjawab rumusan masalah sebagai berikut; (1) bagaimana perencanaan Kepala Kantor Kementerian Agama Kota Jambi dalam meningkat pelayanan publik di bidang Pendidikan Agama Islam (2) bagaimana pelaksanaan Kepala Kantor Kementerian Agama Kota Jambi dalam meningkatkan pelayanan publik di bidang Pendidikan Agama Islam dan (3) bagaimana pengawasan Kepala Kantor Kementerian Agama Kota Jambi dalam meningkatkan pelayanan publik di bidang Pendidikan Agama Islam.

\section{Manajemen Kepala Kantor Kementerian Agama}

Menurut Ibrahim Bafadal, manajemen merupakan proses pendayagunaan semua sumberdaya dalam rangka mencapai tujuan perencanaan, pengorganisasian, pengarahan, dan pengawasan disebut manajemen. ${ }^{5}$ Nanang Fattah, mengemukakan bahwa: "manajemen sebagai proses merencana, mengorganisasi, memimpin dan mengendalikan upaya organisasi dengan segala aspeknya agar tujuan organisasi tercapai secara efektif dan efisien"6.

Terry mengemukakan bahwa manajemen sama dengan manajemen sehingga pengelolahan dipahami sebagai suatu proses membeda-bedakan atas perencanaan, pegorganisasian, penggerakan dan pengawasan dengan memanfaatkan baik ilmu maupun seni agar dapat menyelesaikan tujuan yang telah ditetapkan sebelumnya. ${ }^{7}$

Berdasarkan beberapa pengertian yang dikemukakan oleh para ahli, maka dapat diambil kesimpulan bahwa manajemen adalah suatu proses perencanaan, pelaksanaan, dan pengawasan terhadap aspek-aspek yang ada dalam organisasi dalam rangka pencapaian tujuan organisasi secara efektif dan efisien.

\footnotetext{
3 Observasi Peneliti di Kantor Kementerian Agama Kota Jambi pada tanggal 10 Maret 2016

4 Dokumentasi didapat dari Kantor Kementerian Agama Kota Jambi pada tanggal 10 Maret 2016

5 Ibrahim Bafadal, Manajemen Perlengkapan Sekolah (Jakarta: Bumi Aksara, 2008), hlm.1

${ }^{6}$ Nanang Fattah, Landasan Manajemen pendidikan (Bandung: Remaja Rosdakarya , 2006), hlm.1

7 Terry Goerge R, Prinsip-Prinsip Manajemen. Alih bahasa Smith, J (Jakarta: Bumi Aksra, 2009), hlm. 9
} 
Indikatornya dalam tesis ini adalah perencanaan, pelaksanaan, dan pengevaluasi Kepala Kantor Kementrian Agama Kota Jambi. Sebagai sub indikatornya adalah pelayanan terhadap tenaga pendidik dan kependidikan meliputi pembayaran tunjangan sertifikasi guru, pembayaran tunjangan fungsional guru dan pelayanan NUPTK guru.

Kepala kantor adalah inti dari manajemen. Seorang Kepala kantor adalah seseorang yang aktif membuat rencana-rencana, mengkoordinasi, melakukan percobaan dan memimpin pekerjaan untuk mencapai tujuan bersama-sama. Kementerian Agama mempunyai tugas membantu Presiden dalam menyelenggarakan sebagaian tugas pemerintahan dibidang keagamaan, maka Kementerian Agama Kota Jambi merupakan salah satu satuan kerja Kementerian Agama di Propinsi Jambi, akan menjalankan tugasnya berdasarkan kebijakan Kepala Kantor Wilayah Kementerian Agama Propinsi Jambi dan peraturan perundang undangan yang berlaku. Sesuai dengan Peraturan Menteri Agama Nomor 13 Tahun 2012 Tentang Organisasi dan Tata Kerja Instansi Vertikal Kementerian Agama. Tugas Pokok dan Fungsi Seksi Pendidikan Madrasah di Bagi Ke dalam 5 Bidang Urusan, yaitu: kurikulum dan evaluasi, pendidik dan tenaga kependidikan, sarana dan prasarana, kesiswaan, kelembagaan dan sistem informasi. Pada penelitian ini, peneliti menfokuskan pada pelayanan di bidang pendidikan dan tenaga kependidikan yang meliputi pembayaran tunjangan sertifikasi guru, pembayaran tunjangan fungsional guru, dan pelayanan NUPTK guru.

\section{Fungsi-Fungsi Manajemen}

Fungsi-fungsi manajemen yang dimaksud dalam penelitian ini mengacu kepada fungsi-fungsi manajemen sebagaimana yang diungkapkan oleh Engkoswara, yaitu meliputi fungsi perencanaan, pelaksanaan, dan penilaian. ${ }^{8}$ Perencanaan sering juga disebut jembatan yang menghubungkan kesenjangan atau jurang antara keadaan masa kini dan keadaan yang diharapkan terjadi pada masa yang akan datang. Setiap perencanaan selalu terdapat tiga kegiatan yang meskipun dapat dibedakan, tetapi tidak dapat dipisahkan antara satu dengan yang lainnya dalam proses perencanaan. Ketiga kegiatan itu adalah (1) perumusan tujuan yang ingin dicapai; (2) pemilihan program untuk mencapai tujuan itu; (3) identifikasi dan pengerahan sumber yang jumlahnya selalu terbatas. ${ }^{9}$ Perencanaan diartikan sebagai usaha sadar berupa proses yang sistematik dalam membuat keputusan tentang aktifitasaktifitas dan tujuan-tujuan yang akan dicapai oleh individu, kelompok, unit kerja, atau organisasi pada masa yang akan datang. Berkaitan dengan perencanaan, Bateman \& Snell menyebutkan bahwa karena perencanaan adalah sebuah proses pengambilan keputusan, maka perencanaan harus dilakukan melalui proses tertentu. ${ }^{10}$ Proses perencanaan oleh Bateman \& Snell dibagi dalam enam tahapan, yaitu: analisis keadaan (situational analysis), menetapkan alternatif tujuan dan rencana (alternative goals and plans), mengevaluasi tujuan dan rencana (goal an hlm. 26.

${ }^{8}$ Engkoswara, Dasar-dasar Administrasi Pendidikan (Jakarta: Dirjen Dikti, Depdikbud, 2008),

${ }^{9}$ Nanang Fatah, Landasan Manajemen pendidikan, hlm. 49.

${ }^{10}$ Bateman \& Snell, Management Computing in The New Era, hlm. 112-113. 
plan evaluation), memilih tujuan dan rencana (goal and plan selection), mengimplementasikannya (implementa-tion), memonitor dan mengontrol pelaksanaan (monitor and control). ${ }^{11}$

Pelaksanaan (actuating) merupakan fungsi manajemen yang paling utama.. Dalam hal ini, George R. Terry mengemukakan bahwa actuating merupakan usaha menggerakkan anggota-anggota kelompok sedemikian rupa hingga mereka berkeinginan dan berusaha untuk mencapai sasaran perusahaan dan sasaran anggota-anggota perusahaan tersebut oleh karena para anggota itu juga ingin mencapai sasaran-sasaran tersebut. ${ }^{12}$ Pelaksanaan yang bagus dilakukan oleh Kepala Kantor Kementerian Agama Kota Jambi dalam pelayanan di bidang Pendidikan Agama Islam merupakan pilihan terbaik untuk melaksanakan tugas secara pelayanan prima sesuai dengan SOP. Pelaksanaan pelayanan publik hendaknya dikendalikan untuk pencapaian tujuan-tujuan yang telah ditetapkan dan kontribusinya terhadap perwujudan visi madrasah. Dari setiap pelaksanaan pelayanan publik hendaknya diusahakan suasana yang kondusif, tidak terlalu membebani masyarakat dan tidak merugikan aktivitas masyarakat. Usahakan pelaksanaan kegiatan konsisten sebagaimana terjadwal dan terpublikasikan. ${ }^{13}$

Pengawasan adalah proses pengamatan dari seluruh kegiatan organisasi guna lebih menjamin bahwa semua pekerjaan yang sedang dilakukan sesuai dengan rencana yang telah ditentukan sebelumnya. ${ }^{14}$ selanjutnya pengawasan merupakan proses dasar yang secara esensial tetap diperlukan bagaimanapun rumit dan luasnya suatu organisasi. Proses dasarnya terdiri dari tiga tahap, yaitu: (a) menetapkan standar pelaksanaan, (b) pengukuran pelaksanaan pekerjaan dibandingkan dengan standar, dan (c) menentukan kesenjangan (deviasi) antara pelaksanaan dengan standar dan rencana. ${ }^{15}$ Dalam organisasi apapun, pengawasan itu sendiri selalu diperlukan, karena pengawasan mempunyai sasaran untuk melakukan pencegahan atau perbaikan ketidaksesuaian, kesalahan-kesalahan dan berbagai kelemahan dari suatu pelaksanaan tugas dan wewenang. Adapun fungsi pengawasan menurut Sule dan Saefullah pada dasarnya merupakan proses yang dilakukan untuk memastiakan agar apa yang telah direncanakan berjalan sebagaiamana mestinya. Fungsi pengawasan antara lain identifikasi berbagai faktor yang menghambat sebuah kegiatan, dan juga pengambilan tindakan koreksi yang diperlukan agar tujuan organisasi dapat tetap tercapai. Jika tidak berjalan dengan semestinya maka fungsi pengawasan juga melakukan proses untuk mengoreksi kegiatan yang sedang berjalan agar dapat tetap mencapai apa yang telah direncanakan. ${ }^{16}$

${ }^{11}$ Bateman \& Snell, Management.., hlm. 112-113.

12 George R Terry, Dasar-Dasar Manajemen Edisi Bahasa Indonesia (Jakarta: PT. Bumi Aksara, 2009), hlm. 150

13 George R Terry, Dasar-Dasar Manajemen, hlm. 150.

14 Sondang. P. Siagian, Fungsi-fungsi Manajerial, hlm. 169.

15 Nanang Fatah, Landasan Manajemen Pendidikan, hlm. 101.

16 Sule, Tisnawati, Ernie dan Seafullah Kurniawan, Pengantar Manajemen (Jakarta: Kencana, 2008), hlm. 317. 


\section{Konsep Peningkatan Pelayanan Publik dan Pendidikan Islam}

Secara terminologi, publik atau public mempunyai arti masyarakat atau umum (diperlawankan dengan privat). Istilah public maupun privat berasal dari bahasa latin, di mana public berarti "of the people" (menyangkut rakyat atau masyarakat sebagai bangsa berhadapan dengan negara), sedangkan privat berarti "set a part" (bagian terpisah dari rakyat atau masyarakat), dengan demikian, istilah public dapat disimpulkan sebagai kumpulan orang atau manusia dalam hubungannya dengan dan atau kapasitasnya selaku penyandang kepentingan komunal dari kewarganegaraan suatu negara. Adapun istilah privat menunjuk kepada orang per orang dalam kapasitas individu berhadapan dengan individu yang lain. ${ }^{17}$

Istilah service sering diidentikkan dengan istilah pelayanan. Berkaitan dengan ini Kotler mengemukakan bahwa: "A service is any act of performance that one party can offer to another that is essentially intangible and does not result in the ownership of anything. It's production may or may not be tied in phsycal product". ${ }^{18}$

Dari beberapa pendapat ahli mengenai pelayanan publik,po disimpulkan bahwa dalam pelayanan publik (publik service) terdapat dua pihak yang terlibat didalamnya yaitu pelayanan (servant) dan pelanggan (customer). Dalam hal ini servant merupakan pihak yang menyediakan layanan bagi kebutuhan customer. Konsep ini lebih identik dengan organisasi privat, karena dalam organisasi publik pengertian customer belum sepenuhnya digunakan sebagai pengganti istilah masyarakat dalam hubungan dengan pelayanan. Oleh sebab itu pembicaraan tentang pelayanan kepada masyarakat akan melibatkan empat unsur yang terkait yaitu:19 Pertama, adalah pihak pemerintah atau birokrasi yang melayani. Kedua, adalah pihak masyarakat yang dilayani. Ketiga, terjalin hubungan antara yang melayani dan yang dilayani. Hubungan ini sangat menentukan tingkatan pelayanan pemerintah dan pemanfaatan pelayanan tersebut oleh masyarakat. Keempat, adanya pengaruh lingkungan di luar birokrasi dan masyarakat seperti politik, sosial, budaya dan sebagainya.

Pendidikan sendiri berasal dari kata dasar didik berarti suatu proses pengubahan sikap dan tata laku seseorang dalam usaha mendewasakan manusia melalui upaya pengajaran dan latihan. ${ }^{20}$ Dalam kajiannya, pendidikan mempunyai dua istilah yang hampir sama bentuknya dan sering digunakan yakni paedagogie dan paedagogiek. Paedagogie berarti pendidikan, sedangkan paedagogiek berarti ilmu pendidikan yang menyelidiki serta merenungkan tentang gejala-gejala perbuatan mendidik. ${ }^{21}$

17 Sugiyanto, "Mengukur Kinerja Kebijakan Publik (Pertanyaan Korelasional Terhadap Aktualisasi Good Governance)”, dalam Jurnal Good Governance, Vol 3, No.1, Mei 2006, Program Magister STIA-LAN, Jakarta, hlm. 63-64.

18 Philip Kotler, Manajemen Pemasaran, Analisis, Perencanaan, Implementasi, dan Pengendalian (terj. Supranto), Printice Hall, edisi Indonesia, Jakarta, 1994, hlm. 464.

19 Ibid.,

20 EM Zul Fajri, Ratu Aprilia Senja, Kamus Lengkap Bahasa Indonesia, (tt.: Difa Publisher, 2008), hlm. 254.

${ }^{21}$ M. Djumransjah, Pengantar Filsafat Pendidikan, (Malang: Bayumedia, 2009), hlm. 21 
Dalam mempelajari pendidikan Islam, perlu kiranya memahami makna dari pendidikan Islam terlebih dahulu. Menurut perbendaharaan pendidikan Islam, terdapat tiga istilah yang digunakan untuk menunjukkan makna pendidikan yakni al-tarbiyah, al-ta'lim dan al-ta'dib. ${ }^{22}$ Akan tetapi ada juga yang menambahkan istilah ar-riyadloh. ${ }^{23}$ Ketiganya mempunyai arti yang berbeda sesuai dengan teks dan konteksnya, namun disaat tertentu mereka juga mempunyai sinonim arti. Secara leksikal kosa kata تربية (tarbiyah) berarti pendidikan, تعليم (ta'lim) berarti pengajaran, dan تأديب (ta'dib) berarti pendidikan. ${ }^{24}$ Makna al-tarbiyah lebih luas dari pada maknaal-ta'lim, sedangkan alta'dib mempunyai makna universal dibandingkan makna al-tarbiyah.

Para ahli memberikan pengertian pendidikan dengan redaksi yang berbeda namun esensinya adalah sama. Menurut Djumransjah pendidikan mengandung tujuan yang ingin dicapai, yakni kemampuan individu untuk berkembang sehingga bisa bermanfaat bagi kehidupannya baik sebagai individu, warga negara, maupun warga masyarakat. ${ }^{25}$ Sedangkan pendidikan Islam hakikatnya adalah "proses pembentukan manusia ke arah yang dicita-citakan Islam". ${ }^{26}$

Dari pengertian yang telah dipaparkan oleh beberapa ahli baik secara etimologi maupun terminologi dapat disimpulkan bahwa pendidikan islam adalah proses tranformasi dan internalisasi ilmu pengetahuan dan nilai-nilai pada diri anak didik melalui pertumbuhan dan pengembangan potensi fitrahnya guna mencapai keselarasan dan kesempurnaan hidup dalam segala aspeknya. ${ }^{27}$ Pengertian tersebut sebagaimana kedudukan manusia sebagai hamba Allah serta khalifah Allah di bumi.

Setiap usaha, kegiatan dan tindakan yang di sengaja untuk mencapai tujuan tertentu, harus mempunyai landasan tempat berpijak yang baik dan kuat. Oleh karena itu pendidikan islam sebagai usaha membentuk manusia, harus pula mempunyai landasan yang kuat. Landasan tersebut adalah Al-Quran, As-Sunnah, Ijtihad.

Dalam membahas pendidikan islam, tentunya tidak melupakan rinsip-prinsip pendidikan islam. Sesungguhnya untuk merumuskan tujuan pendidikan islam, harus diketahui terlebih dahulu prinsip-prinsip pendidikan islam yang bersumber dari nilai-nilai Al-Quran dan As-Suannah. Dalam hal ini, paling tidak ada lima prinsip dalam pendidikan islam. Kelima prinsip tersebut antara lain: prinsip integrasi (tauhid), prinsip keseimbangan, prinsip persamaan dan pembebasan, prinsip komunitas dan berkelanjutan (istiqomah), prinsip kemaslahatan dan keutamaan. ${ }^{28}$

\footnotetext{
${ }^{22}$ Azyumardi Azra, Pendidikan Islam: Tradisi dn Modernisasi di Tengah Tantangan Milenium III, (Jakarta: Kencana Prenada Media Group, 2012), hlm. 5.

${ }^{23}$ Akh. Muzakki, Kholilah, Ilmi Pendidikan Islam, (Surabaya: Kopertais IV Press, 2006), hal 9.

24 Rosmiaty Azis, Rekontruksi Pendidikan Islam dalam Era Post-Modernisme Tantangan Menuju Civil Society di Indonesia, tesis, (Makasar: IAIN Alaudin, 2010), hlm. 51.

25 M. Djumransjah, Op.Cit., hlm. 28.

26 Haidar Putra Daulay, Pendidikan Islam: dalam Sistem Pendidikan Nasional di Indonesia, (Jakarta: Kencana, 2008), hlm. 3.

27 Akh. Muzakki, Kholilah, Op.Cit., hal 13.

28 Moh. Roqib, Ilmu Pendidikan Islam: Pengembangan Pendidikan Integratif di Sekolah, Keluarga dan Masyarakat, (Yogyakarta: Lkis Group, 2011), hal 32-33.
} 
Secara prinsipal, tujuan pendidikan Islam ada dua macam, yakni tujuan keagamaan dan tujuan keduniaan. Maksud dari tujuan keagamaan ini adalah bahwa setiap orang muslim secara personal beramal untuk keperluan akhiratnya atas petunjuk dan ilham keagamaan yang benar, yang tumbuh dan berkembang dari ajaran-ajaran Islam yang bersih dan suci. ${ }^{29}$ Pada intinya, tujuan keagamaan ini melalui berbagai metode serta sudut pandangnya baik secara ilmiah maupun falsafiyah akan mengantarkan manusia kepada kebenaran yang haq, yaitu Allah SWT.

\section{Kantor Kementerian Agama Kota Jambi dalam Sejarah}

Berdasarkan Keputusan Menterian Agama RI no. 91 tahun 1967 tentang Struktur Organisasi Tugas dan Wewenang Instansi Departemen Agama Daerah, maka untuk daerah kotamadya Jambi sekarang bernama kota Jambi telah di bentuk Perwakilan Departemen Agama Kotamadya Jambi pada tahun 1968 dengan dinas-dinasnya sebagai berikut: Dinas Urusan Agama Kotamadya Jambi, Dinas Pendidikan Agama Kotamadya Jambi, Dinas Penerangan Kotamadya Jambi, Dinas Urusan Haji Kotamadya Jambi, Dinas Pengadilan Agama Kotamadya Jambi

Pada saat itu Perwakilan Departemen Agama Kotamadya Jambi sekarang bernama Kementerian Agama Kota Jambi yang di kepala oleh Rd. Hasanuddin belum mempunyai gedung kantor yang tetap. Dan pada bulan Desember 1971 barulah Departemen Agama Kotamadya Jambi menempatin Komplek Ex. Perwakilan Departemen Agama Propinsi Jambi yg berada pada jalan Mayang Mengurai sekarang ini bernama Jalan. Prof. DR. Hamka No. 05 kelurahan Beringin Kecamatan Pasar Jambi Kota Jambi.

Adapun visi Kantor Kementerian Agama Kota Jambi adalah: Terwujudnya Masyarakat Kota Jambi Yang Agamais, Cerdas Dan Berkualitas sedangkan misi adalah: meningkatkan kualitas penyeleng-garaan dan pelayanan administrasi secara prima, meningkatkan kwalitas pelayanan bimbingan ibadah, meningkatkan harmonisasi kerukunan umat beragama, meningkatkan kwalitas bimbingan keagamaan pada masya-rakat, dan meningkatkan kwalitas pendidikan pada madrasah dan pondok pesantren.

Dari banyaknya item tugas fungsi Kepala Kantor Kementerian Agama Kota Jambi, maka peneliti lebih mengkaji tentang pelayanan di bidang pendidikan madrasah seperti pelayanan terhadap tenaga pendidik dan kependidikan meliputi pembayaran tunjangan sertifikasi guru, pembayaran tunjangan fungsional guru dan pelayanan NUPTK guru.

Nama - nama Kepala Kantor Kementerian Agama Kota Jambi dari tahun 1974 - sekarang antara lain Ismail Hanafie (1974 - 1977), Drs. H. Anis Husein (1977 - 1989), H. M. Thabrani Kasma, BA (1989 - 1994), Drs. H. Baihaqi Mahidin (1994 - 2000), Drs. Bahrul Hamid, S.Ag (plh)(2000 - 2002), Drs. H. Abdul Kadir Husein (2002 - 2007), Drs. H. Maryadi, M.Pd (2007 - 2010), H. AR. Sayuti, S.Ag (2011 - 2013), Muhammad Ikbal, S.Ag, MH (2013 - Sekarang).

${ }^{29}$ Ali Al Jumbulati, Abdul Futuh At Tuwaanisi, Perbandingan Pendidikan Islam, terj. M. Arifin, Dirasatun Muqaaranatun fit-Tarbiyyatil Islamiyyah, (Jakarta: Rineka Cipta, 2008), cet. 2, hlm. 37. 


\section{Keadaaan Pegawai dan Guru di Kemenag Kota Jambi}

Seksi Pendidikan Madrasah sebagaimana dimaksud dalam pasal 269 PMA Nomor 13 Tahun 2012 mempunyai tugas melakukan pelayanan, bimbingan teknis, pembinaan serta pengelolaan data dan informasi dibidang pendidikan agama Islam pada PAUD, pendidikan dasar, dan pendidikan menengah. Berdasarkan data dari dokumentasi Kantor Kementerian Agama Kota Jambi dapat dilihat bahwa Kantor Kementerian Agama Kota Jambi hanya memiliki 24 orang pegawai struktural, 116 orang orang fungsional umum, 15 orang penghulu, 1 orang arsiparis dan 1orang analis kepegawaian. Secara keseluruhan, pegawai struktural di Kantor Kementerian Agama Kota Jambi sebanyak 157 orang yang berstatus PNS sehingga dalam urusan administrasi tidak mengalami kendala. Di Kantor Kementerian Agama Kota Jambi masih terdapat kekurangan pegawai yang berstatus PNS dalam bidang kebersihan lingkungan, staf kurikulum, staf kepegawaian, dan operator sehingga mengalami kendala dalam menjalankan tugas untuk kepentingan kantor.

Guru Kantor Kementerian Agama Kota Jambi berdasarkan dokumentasi pada tahun 2016 terdiri dari 551 orang guru berstatus PNS, sedangkan jumlah pengawas sebanyak 23 orang yang terdiri dari pengawas MI, MTs, dan MA, dan tenaga fungsional penyuluh sebanyak 35 orang yang tersebar di wilayah Kota Jambi. Adapun seluruh guru sudah berkualifikasi pendidikan S1, sesuai dengan tuntutan UU Nomor 20 Tahun 2003 tentang Sistem Pendidikan Nasional dan UU Nomor 14 Tahun 2005 Tentang Guru dan Dosen. Dengan data keadaan guru tersebut di atas diperlukan pimpinan sekolah yang memiliki kemampuan dan keahlian sehingga dapat menata suasana kerja yang baik sehinga terbentuk iklim kerja yang kondusif bagi guru dalam melaksanakan tugas keguruannya dan pegawai tidak dirugikan, selanjutnya tujuan pembekerjaan dapat tercapai dengan baik dan sesuai dengan yang diharapkan. Begitu pula pengawas dan penyuluh agama di Kementerian Agama Kota Jambi sudah sesuai dengan kompetensi pendidikan.

\section{Sarana dan Prasarana Kementerian Agama Kota Jambi}

Kantor Kementerian Agama Kota Jambi sebagai sebuah lembaga pelayanan pendidikan dan masyarakat berdasarkan data dokumentasi, pada saat ini memiliki sarana dan prasrana pendidikan terdiri dari 9 ruang bekerja, 1 ruang Kepala Kantor Kementerian Agama Kota Jambi, 1 ruang Kasubbag TU, 5 ruang Kepala Seksi, 1 ruang pengawas, 1 musholla, 1 buah lapangan bola pimpong dan 1 lapangan upacara. Akan tetapi, sarana prasarana WC pegawai yang kurang baik menyebabkan pegawai membuang air kecil dan besar bergabung dengan WC kepala seksi. Selain itu, Kantor Kementerian Agama Kota Jambi masih terdapat kekurangan seperti tidak memiliki ruang tunggu, parkir, taman atau kebun. Sehingga dapat menghambat proses pelayanan publik di Kantor Kementerian Agama Kota Jambi dalam meningkatkan pelayanan publik di bidang Pendidikan Agama Islam. 
Sarana yang dimiliki Kantor Kementerian Agama Kota Jambi terdapat 2 kursi dan meja pegawai fungsional umum dan 1 komputer kurang baik. Dengan kurang baik kondisi meja dan kursi pegawai dan sarana komputer menyebabkan dapat menganggu pegawai dalam bekerja. Di Kantor Kementerian Agama Kota Jambi keadaan sarana dan prasarana penunjang pelaksanaan pelayanan publik masih sangat jauh dari standar yang ditetapkan oleh Kementerian Agama menetapkan standar sarana dan prasarana yang harus dimiliki oleh sebuah kantor meliputi: gedung/ruang bekerja, ruang pimpinan, ruang Kasubbag Tata Usaha, perpustakaan, sarana olah raga, musholla, tempat bermain, taman, fasilitas kesehatan, dan keselamatan bagi pegawai, dan sarana lain sesuai dengan tuntutan program pelayanan publik yang diselenggarakan oleh kantor.

\section{Manajemen Kepala Kantor Kementerian Agama Kota Jambi dalam Peningkatan Pelayanan Publik di Bidang Pendidikan Agama Islam}

\section{Perencanaan Kepala Kantor Kementerian Agama Kota Jambi dalam Meningkatkan Pelayanan Publik Di Bidang Pendidikan Agama Islam}

Berdasarkan dokumen Kantor Kementerian Agama Kota Jambi dalam meningkatkan pelayanan publik di bidang Pendidikan Agama Islam bahwa perencanaan Kepala Kantor Kementerian Agama Kota Jambi dalam meningkatkan pelayanan publik di bidang Pendidikan Agama Islam meliputi proses pelayanan terhadap tenaga pendidik dan kependidikan meliputi pembayaran tunjangan sertifikasi guru, pembayaran tunjangan fungsional guru dan pelayanan NUPTK guru. Bilamana bahan yang diajukan oleh guru sudah lengkap, guru dikehendaki untuk menunggu proses penyelesaian dalam waktu yang telah ditentukan sesuai dengan SOP. Untuk pelayanan tunjungan sertifikasi guru dan tunjangan fungsional guru diselesaikan dalam waktu selama 2-3 hari, sedangkan pelayanan NUPTK guru diselesaikan dalam waktu 1-2 hari.

Selanjutnya berdasarkan dokumen Kantor Kementerian Agama Kota Jambi dalam meningkatkan pelayanan publik di bidang Pendidikan Agama Islam bahwa perencanaan Kepala Kantor Kementerian Agama Kota Jambi dalam meningkatkan pelayanan publik di bidang Pendidikan Agama Islam meliputi pelayanan terhadap tenaga pendidik dan kependidikan meliputi pembayaran tunjangan sertifikasi guru, pembayaran tunjangan fungsional guru dan pelayanan NUPTK guru melalui tiga tahap perencanaan. Perancanaan jangka pendek, sebagai Kepala Kantor Kementerian Agama Kota Jambi mengadakan rapat dengan semua pegawai membicarakan masalah kegiatan Kantor Kementerian Agama Kota Jambi dalam meningkatkan pelayanan publik di bidang Pendidikan Agama Islam. Pada tahap jangka pendek meliputi program harian, mingguan, dan bulanan. Perancanaan jangka menengah meliputi kegiatan pegawai melaksanakan tugas melayani guru mengenai tunjangan fungsional guru. 
Perencanaan jangka panjang seperti melayani guru untuk menyelesaikan masalah NUPTK guru. Semua perencanaan kegiatan Kantor Kementerian Agama Kota Jambi dalam meningkat pelayanan publik di bidang Pendidikan Agama Islam telah direncanakan secara optimal, namun walaupun demikian terdapat juga berbagai kelemahannya. ${ }^{30}$

Beberapa hal yang dapat dilakukan Kepala Kantor Kementerian Agama Kota Jambi dalam meningkatkan pelayanan publik di bidang Pendidikan Agama Islam ini adalah: (1) memberikan orientasi kepada pegawai untuk melaksanakan tugas pokok yang wajib dikerja di kantor dengan tepat waktu, (2) membuat jurnal jenis kegiatan Kepala Kantor Kementerian Agama Kota Jambi dalam meningkatkan pelayanan publik di bidang Pendidikan Agama Islam, (3) mencatat prestasi pegawai dalam memberi pelayanan prima terhadap tenaga tenaga pendidik dan kependidikan meliputi pembayaran tunjangan sertifikasi guru, pembayaran tunjangan fungsional guru dan pelayanan NUPTK guru, dan (4) mengatur jadwal pelayanan terhadap tenaga pendidik dan kependidikan meliputi pembayaran tunjangan sertifikasi guru, pembayaran tunjangan fungsional guru dan pelayanan NUPTK guru.

Berdasarkan observasi peneliti di lapangan bahwa Kepala Kantor Kementerian Agama Kota Jambi sudah melakukan perencanaan dalam meningkatkan pelayanan publik di bidang Pendidikan Agama Islam seperti pelayanan terhadap tenaga pendidik dan kependidikan meliputi pembayaran tunjangan sertifikasi guru, pembayaran tunjangan fungsional guru dan pelayanan NUPTK guru sudah dilakukan dengan baik, namun Kepala Kantor Kementerian Agama Kota Jambi kurang memberikan dukungan moril terhadap pegawai dalam melaksanakan bentuk-bentuk kegiatan yang ada di Kantor Kementerian Agama Kota Jambi dalam meningkatkan pelayanan publik di bidang Pendidikan Agama Islam dengan alasan dana yang tersedia kurang. Sebab bila dilakukan berbagai bentuk kegiatan di Kantor Kementerian Agama Kota Jambi dalam meningkatkan pelayanan publik di bidang Pendidikan Agama Islam perlu dibentuk penanggung jawaban masing-masing kegiatan tersebut. Untuk mengimbangi dana yang tersedia, Kepala Kantor Kementerian Agama Kota Jambi hanya mendukung pelayanan terhadap tenaga pendidik dan kependidikan seperti pembayaran tunjangan sertifikasi guru, pembayaran tunjangan fungsional guru dan pelayanan NUPTK guru. Sedangkan kegiatan yang lain diabaikan, sehingga bila ada pemeriksaan terhadap pegawai Kantor Kementerian Agama Kota Jambi tidak memperoleh prestasi yang baik dalam bidang seksi Pendidikan Madrasah. ${ }^{31}$

Analisis temuan di lapangan, di mana perencanaan Kepala Kantor Kementerian Agama Kota Jambi dalam meningkatkan pelayanan publik di bidang Pendidikan Agama Islam seperti pelayanan terhadap tenaga pendidik dan kependidikan meliputi pembayaran tunjangan sertifikasi guru, pembayaran tunjangan fungsional guru dan pelayanan NUPTK guru tidak dilakukan sepenuh hati seperti dalam penyelesaian berkas NUPTK guru diselesaikan selama 1 minggu.

30 Dokumen Perencanaan Kantor Kementerian Agama Kota Jambi Tahun 2016

31 Observasi Peneliti di Kantor Kementerian Agama Kota Jambi Tanggal 28 September 2016 Kota Jambi, Perencanaan Kepala Kantor Kementerian Agama Kota Jambi Dalam Meningkatkan Pelayanan Publik di Bidang Pendidikan Agama Islam. 
Di samping itu pelanggan (guru) tidak setuju terhadap kebijakan yang dibuat oleh Kepala Kantor Kementerian Agama Kota Jambi, sebab dalam SOP sudah jelas bahwa penyelesaian urusan pembayaran tunjangan sertifikasi guru, pembayaran tunjangan fungsional guru dan pelayanan NUPTK guru diselesai selama 1 hari sampai 2 hari hanya sebagai embel saja. Lebih lanjut Kepala Kantor Kementerian Agama Kota Jambi telah membuat perencanaan kegiatan dalam meningkatkan pelayanan publik di bidang Pendidikan Agama Islam seperti pembayaran tunjangan sertifikasi guru, pembayaran tunjangan fungsional guru dan pelayanan NUPTK guru adalah sesuai dengan perioritasnya. Namun, dalam praktiknya masih terdapat pegawai yang selalu mengulur-ulur waktu menyelesaikan berkas yang diinginkan oleh guru. Disamping itu Kepala Kantor Kementerian Agama Kota Jambi nampaknya tidak memberikan sanksi yang tegas kepada pegawainya dalam melaksanakan tugasnya yang tidak sesuai dengan SOP dalam meningkatkan pelayanan publik di bidang Pendidikan Agama Islam yang dilakukan oleh pegawai. Seharusnya sesuai dengan aturan yang berlaku, pegawai yang tidak melaksanakan tugasnya dengan optimal perlu diberikan sanksi, supaya semua pegawai melaksanakan tugas dengan penuh disiplin sesuai dengan SOP.

Kepala Kantor Kementerian Agama Kota Jambi belum membuat perencanaan yang bagus dalam meningkatkan pelayanan publik di bidang Pendidikan Agama Islam seperti pelayanan terhadap tenaga pendidik dan kependidikan meliputi pembayaran tunjangan sertifikasi guru, pembayaran tunjangan fungsional guru dan pelayanan NUPTK guru, sehingga banyak pelayanan publik tidak berjalan dengan efektif karena tidak adanya dukungan dari Kepala Kantor Kementerian Agama Kota Jambi baik moril dan materil. Adapun kegiatan yang menjadi perioritas Kepala Kantor Kementerian Agama Kota Jambi dalam meningkatkan pelayanan publik di bidang Pendidikan Agama Islam adalah hanya pelayanan pembayaran tunjangan fungsional guru.

\section{Faktor-faktor Penghambat Perencanaan Kepala Kantor Kementerian Agama Kota Jambi Dalam Meningkatkan Pelayanan Publik di Bidang Pendidikan Agama Islam}

Faktor penghambat perencanaan Kepala Kantor Kementerian Agama Kota Jambi dalam meningkatkan pelayanan publik di bidang Pendidikan Agama Islam berdasarkan observasi peneliti di lapangan adalah faktor internal dan faktor eksternal. Faktor internal meliputi faktor fisiologis, faktor psikologis, perhatian, minat, motivasi dan bakat pegawai. Sedangkan faktor eksternal terdiri dari faktor sosial dan faktor non sosial. Faktor sosial antara lain seperti keadaan keluarga, keadaan lingkungan kantor, lingkungan masyarakat.

Selain itu, berdasarkan observasi peneliti bahwa faktor-faktor penghambat perencanaan kegiatan pegawai seksi Pendidikan Madrasah di Kantor Kementerian Agama Kota Jambi dalam meningkatkan pelayanan publik di bidang Pendidikan Agama adalah sebagai berikut: a) faktor pegawai, yang memiliki latar belakang yang berbeda, maka tingkat keseriusan bekerja juga berbeda-beda, dan para pegawai mempunyai sifat matrealistis sehingga sulit untuk diajak untuk ikut membuat program kegiatan tugas di Kantor Kementerian Agama Kota Jambi dalam meningkatkanpelayanan publik di bidang Pendidikan Agama Islam, b) faktor dari guru yang kurang mempunyai waktu untuk berurusan di Kantor Kementerian 
Agama Kota Jambi, c) faktor sarana dan prasarana yang masih belum memadai, d) faktor lingkungan dimana masyarakat justru membiarkan pegawai seksi pendidikan madrasah dalam menyelesaikan urusan guru dalam waktu yang sangat lama, dan e) faktor kurangnya pengawasan. ${ }^{32}$

Upaya Kepala Kantor Kementerian Agama Kota Jambi Dalam Perencanaan Meningkatkan Pelayanan Publik di Bidang Pendidikan Agama Islam

Berdasarkan observasi peneliti di lapangan bahwa upaya yang dilakukan oleh Kepala Kantor Kementerian Agama Kota Jambi dalam merencanakan kegiatan untuk meningkatkan pelayanan publik di bidang Pendidikan Agama adalah dengan menumbuhkan konsep diri kepada pegawai sehingga pegawai dapat berperilaku agamis seperti: keterampilan komunikasi, konsekuensi-konsekuensi logis dan alami, klarifikasi nilai (contoh: nilai kerapihan), analisis transaksional (tahapan yang dilalui dan disepakati bersama). Untuk itu pada hakikatnya membuat pegawai menjadi lebih teratur dan lebih baik dalam bekerja, bukan malah tertekan ataupun merasa terbebani. Kepala Kantor Kementerian Agama Kota Jambi sebagai pembina pegawai sudah sepantasnya memberikan keteladanan kepada para pegawainya. Agar nantinya mereka terbiasa disiplin pada lingkungan kerja, karena dengan pelayanan yang baik diberikan oleh pegawai seksi pendidikan madrasah guru merasa dihargai. ${ }^{33}$ Upaya lain yang dilakukan Kepala Kantor Kementerian Agama Kota Jambi adalah membuat perencanaan yang lebih untuk meningkatkan pelayanan publik di bidang Pendidikan Agama Islam karena selama ini perencanaan yang dihasilkan tidak bagus, sehingga membingung pegawai seksi pendidikan madrasah untuk melaksanakan tugasnya sehari-hari. ${ }^{34}$

\section{Pelaksanaan Kepala Kantor Kementerian Agama Kota Jambi Dalam Meningkatkan Pelayanan Publik Di Bidang Pendidikan Agama Islam}

Untuk memberikan suatu pelayanan yang baik bagi guru diperlukan adanya suatu standar yang harus dipatuhi oleh semua pegawai Kantor Kementerian Agama Kota Jambi yang ditetapkan melalui Standar Pelayanan Minimal. Standar ini bukan hanya mencakup prosedur kerja namun juga keseragaman layanan dan kesamaan persepsi. Oleh sebab itulah keberadaan suatu standar baku dalam bentuk SOP sangat urgent dalam rangka mewujudkan pelaksanaan tugas menjadi lebih efisien, efektif, transparan dan akuntabel serta terciptanya pelayanan prima kepada para pengguna layanan serta meningkatkan kepercayaan dan kepuasan guru terhadap Kantor Kementerian Agama Kota Jambi.

32 Observasi Peneliti di Kantor Kementerian Agama Kota Jambi Tanggal 10 Oktober 2016 Kota Jambi, Faktor-Faktor Penghambat Perencanaan Kepala Kantor Kementerian Agama Kota Jambi Dalam Meningkatkan Pelayanan Publik di Bidang Pendidikan Agama Islam.

33 Observasi Peneliti. Tanggal 12 Oktober 2016 Kota Jambi, Upaya Kepala Madrasah Dalam Perencanaan Kepala Kantor Kementerian Agama Kota Jambi Dalam Meningkatkan Pelayanan Publik di Bidang Pendidikan Agama Islam.

34 Observasi Peneliti di Kantor Kementerian Agama Kota Jambi Tanggal 15 Oktober 2016 Kota Jambi, Upaya Kepala Madrasah Dalam Perencanaan Kepala Kantor Kementerian Agama Kota Jambi Dalam Meningkatkan Pelayanan Publik di Bidang Pendidikan Agama Islam. 
Kepala Kantor Kementerian Agama Kota Jambi telah melakukan peningkatan pelayanan publik di bidang Pendidikan Agama Islam dengan melatih pegawai untuk menumbukan prestasi yang bagus dalam bekerja. Keseriusan Kepala Kantor Kementerian Agama Kota Jambi dalam meningkatkan pelayanan publik adalah kepala bersama dengan kasi Pendidikan Madrasah selalu melakukan pengawas terhadap pegawai dalam bekerja. Bila terdapat pegawai dalam melayani guru yang tidak sesuai dengan SOP, akan diberikan teguran baik secara lisan atau tertulis. Bila teguran tidak dijalankan oleh pegawai tersebut, Kepala Kantor Kementerian Agama Kota Jambi membuat surat panggilan sebanyak 3 kali, pegawai tersebut belum juga melakukan perubahan maka Kepala Kantor Kementerian Agama Kota Jambi membuat surat skoring pegawai tersebut dengan tidak memberikan uang makan.

Berdasarkan observasi peneliti selanjutnya dapat diperoleh data, di mana tidak semua pegawai yang bekerja di Kantor Kementerian Agama Kota Jambi dapat meningkatkan pelayanan publik di bidang Pendidikan Agama Islam seperti pelayanan terhadap tenaga pendidik dan kependidikan meliputi pembayaran tunjangan sertifikasi guru, pembayaran tunjangan fungsional guru dan pelayanan NUPTK guru sebagai indikator meningkatkan prestasi kerja pegawai. Malah terdapat pegawai yang melaksanakan tugas pelayanan publik di bidang Pendidikan Agama Islam mendapat prestasi yang buruk dalam bekerja. Apalagi pegawai yang melaksanakan tugasnya tidak sesuai dengan SOP, hasil yang diperoleh pegawai dalam melayani guru memperoleh prestasi kerja yang rendah. Selanjutnya dalam pelaksanaan tugas Kepala Kantor Kementerian Agama Kota Jambi melalui bawahannya dalam meningkatkan pelayanan publik di bidang Pendidikan Agama Islam seperti pelayanan terhadap tenaga pendidik dan kependidikan meliputi pembayaran tunjangan sertifikasi guru, pembayaran tunjangan fungsional guru dan pelayanan NUPTK guru dapat meningkatkan prestasi kerja pegawai. Dimana pegawai yang melaksanakan tugasnya di Kantor Kementerian Agama Kota Jambi dalam meningkatkan pelayanan publik di bidang Pendidikan Agama Islam dapat meningkatkan prestasi kerja pegawai dalam melaksanakan tugasnya, sehingga segala proses bekerja pegawai dilakukan secara serius sesuai dengan SOP yang ada. Selanjutnya bagi pegawai yang melaksanakan tugas dengan penuh berprestasi dalam pelayanan publik untuk menghindari guru dan masyarakat tidak merasa kecewa berurusan di seksi pendidikan madrasah, dalam hal ini Kantor Kementerian Agama Kota Jambi dikagumi oleh kantor lain yang ada di Kota Jambi. Kalau saya lihat, banyak pegawai Kantor Kementerian Agama Kota Jambi yang berprestasi dalam melaksanakan tugasnya dalam meningkatkan pelayanan publik di bidang Pendidikan Agama Islam. Di samping itu pegawai yang berprestasi dalam bekerja di Kantor Kementerian Agama Kota Jambi dalam meningkatkan pelayanan publik di bidang Pendidikan Agama Islam pegawai tersebut terampil bagus dalam segala hal di lingkungan perkantoran, dan guru merasa dilayani dengan bagus oleh pegawai di seksi pendidikan madrasah. Sebuah tolak ukur tercapainya efektivitas kerja pegawai adalah dengan melihat tingkat prestasi kerja mereka, karena prestasi kerja merupakan hasil yang dicapai oleh seseorang dalam melaksanakan setiap pekerjaannya. Prestasi kerja pegawai di Kantor Kementerian Agama Kota Jambi tergolong masih kurang. Walaupun sejumlah pekerjaan dapat diselesaikan dengan baik, namun ada beberapa kendala 
yang dikatakan bisa menghambat pekerjaan mereka. Selain itu, ada beberapa staf yang masih kurang dalam menguasai komputer. Namun disamping kekurangankekurangan tersebut, yang paling penting adalah pegawai-pegawai tersebut sangat bertanggung jawab terhadap pekerjaan yang mereka emban, inilah yang menjadi kunci dapat diselesaikannya pekerjaan yang mereka hadapi walaupun harus dihadapkan dengan berbagai kendala. ${ }^{35}$

Faktor-Faktor Penghambat Pelaksanaan Kepala Kantor Kementerian Agama Kota Jambi dalam Meningkatkan pelayanan publik di bidang Pendidikan Agama Islam

Faktor penghambat Kepala Kantor Kementerian Agama Kota Jambi dalam melaksanakan tugasnya dalam pelayanan publik di Kantor Kementerian Agama Kota Jambi dalam meningkat pelayanan publik di bidang Pendidikan Agama Islam di Kantor Kementerian Agama Kota Jambi antara lain faktor lingkungan rumah tangga, faktor hubungan antar pegawai, faktor kesulitan ekonomi, faktor lingkungan luar kantor, faktor fasilitas kantor, faktor pihak guru dan faktor pegawai.

Upaya Yang Dilaksanakan Kepala Kantor Kementerian Agama Kota Jambi Dalam Dalam Meningkatkan Pelayanan Publik di Bidang Pendidikan Agama Islam

Upaya yang dilakukan Kepala Kantor Kementerian Agama Kota Jambi untuk mengatasi faktor-faktor penghambatan dalam pelayanan adalah dengan mengadakan pendidikan dan pelatihan bagi pegawai untuk menambah wawasan dan pengawai yang sesuai dengan tugas yang dilakukan, meberikan bimbingan dan penyuluhan serta melakukan evaluasi kinerja.

Pengawasan Kepala Kantor Kementerian Agama Kota Jambi Dalam Meningkatkan Pelayanan Publik di Bidang Pendidikan Agama Islam

Tidak terjadinya peningkatan kualitas pegawai dalam melaksanakan berbagai aktivitas di kantor Kepala Kantor Kementerian Agama Kota Jambi tidak memberi sejenis penghargaan kepada pegawai yang telah melaksanakan tugasnya dengan baik sesuai SOP, bahkan terdapat pegawai yang memenangi berbagai perlombaan pegawai teladan. Hal ini membawa pengaruh terhadap pegawai, dimana mereka kurang semangat untuk melaksanakan tugas dan kewajibannya dalam meningkatkan pelayanan publik di bidang Pendidikan Agama Islam tersebut. ${ }^{36}$

35 Observasi Peneliti di Kantor Kementerian Agama Kota Jambi Tanggal 25 Oktober 2016 Kota Jambi, Pelaksanaan Kepala Kantor Kementerian Agama Kota Jambi Dalam Meningkatkan Pelayanan Publik di Bidang Pendidikan Agama Islam.

36 Observasi Peneliti. Tanggal 17 Nopember 2016 Kota Jambi, Pengawasan Kepala Kantor Kementerian Agama Kota Jambi Dalam Meningkatkan Pelayanan Publik di Bidang Pendidikan Agama Islam. 
Faktor-Faktor Penghambat Pengawasan Kepala Kantor Kementerian Agama Kota Jambi Dalam Meningkatkan Pelayanan Publik di Bidang Pendidikan Agama Islam

Faktor penghambat dalam melakukan tugas pada pegawai di Kantor Kementerian Agama Kota Jambi antara lain: 1) Kurangnya taraf kesadaran dari pegawai dalam melaksanakan tugas yang diberikan oleh atasannya, 2) kurangnya motivasi intrinsik. Dari pihak atasan, 3) kurangnya rasa bertanggung jawab, 4) kurangnya rasa malu pegawai. ${ }^{37}$

Upaya Yang Dilakukan Kepala Kantor Kementerian Agama Kota Jambi Dalam Melakukan Pengawasan Untuk Meningkatkan Pelayanan Publik di Bidang Pendidikan Agama Islam.

Upaya Kepala Kantor Kementerian Agama Kota Jambi untuk meningkatkan pelaksanaan pelayanan publik di bidang Pendidikan Agama Islam adalah dengan memberikan teguran, pemanggilan, ditunda gaji berkala, penundaan kenaikan pangkat, pemberian rekomendasi untuk dikeluarkan dari kantor bagi pegawai yang tidak melaksanakan layanan sesuai SOP. ${ }^{38}$

\section{Upaya Kepala Kantor Kementerian Agama dalam Memberikan Pelayanan Publik Bidang Pendidikan Agama Islam}

Usaha Kepala Kantor Kementerian Agama Kota Jambi dalam meningkatkan pelayanan publik di bidang Pendidikan Agama Islam adalah usaha kantor untuk memelihara perilaku pegawai agar tidak menyimpang dan dapat mendorong pegawai untuk melaksanakan tugas sesuai dengan SOP yang berlaku, berperilaku sesuai dengan norma, peraturan kantor. Tujuan dari Kepala Kantor Kementerian Agama Kota Jambi dalam meningkatkan pelayanan publik di bidang Pendidikan Agama Islam adalah memberi dukungan bagi terciptanya perilaku yang tidak menyimpang bagi pegawainya melaksanakan tugas dalam melayani orang yang berurursan di kantor, mendorong pegawai melakukan tugasnya yang baik dan benar, membantu pegawai memahami dan menyesuaikan diri dengan tuntunan lingkungan dan menjauhi melakukan hal-hal yang tidak sesuai norma.

Perencanaan sering juga disebut jembatan yang menghubungkan kesenjangan atau jurang antara keadaan masa kini dan keadaan yang diharapkan terjadi pada masa yang akan datang. Selanjutnya Nanang Fatah juga menyebutkan bahwa dalam setiap perencanaan selalu terdapat tiga kegiatan yang meskipun dapat dibedakan, tetapi tidak dapat dipisahkan antara satu dengan yang lainnya dalam proses perencanaan. Ketiga kegiatan itu adalah (1) perumusan tujuan yang ingin dicapai; (2) pemilihan program untuk mencapai tujuan itu; (3) identifikasi dan pengerahan sumber yang jumlahnya selalu terbatas.

37 Observasi Peneliti. Wawancara 18 Desember 2016 Kota Jambi, Faktor Penghambat Pengawasan Kepala Kantor Kementerian Agama Kota Jambi Dalam Meningkatkan Pelayanan Publik di Bidang Pendidikan Agama Islam.

38 Observasi Peneliti. Tanggal 23 Nopember 2016 Kota Jambi, Upaya Yang Dilakukan Untuk Pengawasan Kepala Kantor Kementerian Agama Kota Jambi Dalam Meningkatkan Pelayanan Publik di Bidang Pendidikan Agama Islam. 
Mengacu kepada berbagai pandangan tentang konsep perencanaan Kepala Kantor Kementerian Agama Kota Jambi dalam meningkatkan pelayanan publik di bidang Pendidikan Agama Islam seperti pelayanan terhadap tenaga pendidik dan kependidikan meliputi pembayaran tunjangan sertifikasi guru, pembayaran tunjangan fungsional guru dan pelayanan NUPTK guru yang efektif ditandai dengan indikator-indikator sebagai berikut: a) keterlibatan para personil pegawai yang berkompeten dalam penyusunan rencana. b) proses penyusunan rencana sesuai dengan waktu yang telah ditetapkan. c) penyusunan rencana kerja tidak menggunakan biaya terlalu banyak (sesuai anggaran). d) pemanfaatan sarana dan prasarana yang ada dapat memenuhi kebutuhan proses penyusunan rencana. e) penyusunan perencanaan memenuhi unsur-unsur dan langkah-langkah proses penyusunan perencanaan. f) proses penyusunan perencanaan menghasilkan visi, misi, dan tujuan pembinaan kepegawaian yang jelas. g) proses penyusunan perencanaan menghasilkan program/rencana tugas pegawai yang jelas, terarah dan terstruktur.

Perencanaan Kepala Kantor Kementerian Agama Kota Jambi dalam meningkatkan pelayanan publik di bidang Pendidikan Agama Islam di Kantor Kementerian Agama Kota Jambi seperti pelayanan terhadap tenaga pendidik dan kependidikan meliputi pembayaran tunjangan sertifikasi guru, pembayaran tunjangan fungsional guru dan pelayanan NUPTK guru belum dilakukan secara maksimal, dimana Kepala Kantor Kementerian Agama Kota Jambi dalam membuat perencanaan kegiatan Kepala Kantor Kementerian Agama Kota Jambi dalam meningkatkan pelayanan publik di bidang Pendidikan Agama Islam tidak mengikuti aturan yang ada seperti membuat perencanaan hanya pada program jangka pendek, sedangkan program jangka menengah dan panjang tidak dibuat secara baik. Sehingga berbagai bentuk kegiatan di Kantor Kementerian Agama Kota Jambi dalam meningkatkan pelayanan publik di bidang Pendidikan Agama Islam yang dilaksanakan oleh pegawainya, tidak pernah menoreh prestasi yang baik. Dimana guru merasakan pelayanan yang diberikan oleh pegawai masih banyak kekurangan. Disamping itu, Kepala Kantor Kementerian Agama Kota Jambi lebih memfokus pada program pembinaan pegawai seperti disiplin kerja pegawai, itu pun setengah hati. Sehingga menyebabkan pegawai dalam bekerja tidak mengikuti SOP yang ada. ${ }^{39}$

Selanjutnya Kepala Kantor Kementerian Agama Kota Jambi dalam meningkatkan pelayanan publik di bidang Pendidikan Agama Islam seperti pelayanan terhadap tenaga pendidik dan kependidikan meliputi pembayaran tunjangan sertifikasi guru, pembayaran tunjangan fungsional guru dan pelayanan NUPTK guru merupakan nilai-nilai Akhlak pegawai yang dikembangkan di kantor, diantaranya berhati lembut, bekerja keras, tekun dan ulet, dinamis total dan produktif, sabar dan tawakal serta loyal, terbiasa beretika baik dalam perilaku sehari-hari, terbiasa berpikir kritis, sederhana. Sportif dan tanggung jawab, terbiasa berperilaku Qana'ah, toleran, peduli terhadap lingkungan dan budaya serta tidak sombong, tidak merusak, tidak nifak dan beretika baik dalam melaksanakan tugas. Nilai Islam yang dibina di kantor secara garis besar dibagi

39 Muhammad Alim, Pendidikan Agama Islam Upaya Pembentukan Pemikiran dan Kepribadian Muslim (Bandung: PT Remaja Rosdakarya, 2011), hlm. 122 
menjadi dua yaitu nilai kepribadian dan nilai akhlak mulia. Nilai kepribadian meliputi kesehatan, tanggung jawab, percaya diri, dan kompetitif pegawai. Sedangkan nilai akhlak mulia meliputi: nilai kedisiplinan, kebersihan, sopan santun, hubungan sosial, kejujuran, dan ketaatan ibadah. Nilai Islam yang akan dibahas meliputi nilai kedisiplinan, tanggung jawab, percaya diri, hubungan sosial dan kegiatan Ibadah pegawai. ${ }^{40}$

Adapun tugas pokok pegawai seksi Pendidikan Madrasah sebagai abdi negara dan pelayan masyarakat, yaitu pelayanan terhadap tenaga pendidik dan kependidikan meliputi pembayaran tunjangan sertifikasi guru, pembayaran tunjangan fungsional guru dan pelayanan NUPTK guru. Dalam setiap tugas pegawai pada seksi pendidikan madrasah tersebut lebih menekankan pada disiplin terhadap ketepatan waktu melayani guru. Setiap tugas yang dilakukan oleh pegawai pada seksi pendidikan madrasah tersebut, setiap pegawai berusaha dengan sungguh-sungguh melaksanakan tugas yang diembannya. Di samping itu pegawai pada seksi pendidikan madrasah dapat melakukan tugas yang baik melalui pembinaan pegawai di Kantor Kementerian Agama Kota Jambi melalui pendidikan dan pelatihan untuk menambah wawasan dan pengetahun pegawai dalam melayani guru sesuai dengan waktu dan tidak menyusahkan pelanggan. Dengan adanya ketepatan waktu yang dilakukan oleh pegawai dalam melayani guru untuk menghindari terganggunya tugas yang dilaksanakan di sekolah. .

Peningkatan kualitas pelayanan publik sekarang juga telah menjadi salah satu parameter penilaian tingkat kemajuan reformasi birokrasi dan penyelenggaraan pemerintahan yang baik. Program peningkatan kualitas pelayanan publik bertujuan untuk meningkatkan kualitas pelayanan publik dari masing-masing instansi pemerintah sesuai dengan kebutuhan dan harapan guru Indonesia. Seiring dengan inovasi pelayanan publik, tuntutan guru terhadap pelayanan prima dan berkualitas akan semakin menguat. Jika demikian maka penyelenggara pelayanan harus menanggapinya dengan inovasi pelayanan yang terus menerus. Sehingga kepuasan masyarakat juga semakin meningkat. Penetapan standar pelayanan setidaknya harus memuat persyaratan dan prosedur pelayanan, jangka waktu penyelesaian, biaya pelayanan, dan mekanisme pengaduan bagi warga yang kurang puas sebagai masukan perbaikan kualitas pelayanan.

Salah satu kunci pelayanan berkualitas terletak pada cara petugas memberikan pelayanan. Petugas pelayanan publik diharapkan untuk melayani secara komunikatif, ramah, profesional dan berintegritas. Untuk itu kegiatan penunjang perlu dilakukan seperti pelatihan pelayanan pelanggan untuk petugas pelayanan, survei kepuasan masyarakat, serta pemberian reward dan punishment. Bagi masyarakat yang ingin memberi-kan respon penyelenggara perlu menyediakan fasilitas pengaduan seperti adanya call center yang dapat dihubungi masyarakat dengan mudah.

Di kantor kementerian agama kota jambi, pelayanan sudah mulai banyak terlihat inovasi pelayanan seperti layanan dengan waktu yang singkat dan tepat. Hal inilah yang harus terus dipertahankan bahkan dikembangkan oleh pegawai kantor dalam memberikan pelayanan publik di masa yang akan datang. Reformasi birokrasi pelayanan publik akan mengubah wajah suatu badan pelayanan publik

40 Abdul Majid dan Dian Andayani, Pendidikan Karakter Perspektih Al Qur'an (Bandung: PT Remaja Rosdakarya, 2012), hlm. 169 
dan menjadi pembelajaran bagi pelayanan publik lainnya. Terus berkembang sampai seluruh pelayanan publik dapat menyediakan pelayanan dengan cepat, tepat, dan memuaskan, oleh ASN yang profesional, ramah, dan berintegritas tinggi. ${ }^{41}$

Kegiatan Kepala Kantor Kementerian Agama Kota Jambi dalam meningkatkan pelayanan publik di bidang Pendidikan Agama Islam di Kantor Kementerian Agama Kota Jambi yang belum optimal yaitu kegiatan esktrakurikuler yang dilakukan di luar jam pelajaran seperti pagi hari dan sore hari, pegawai mengikuti kegiatan pelayanan terhadap tenaga pendidik dan kependidikan meliputi pembayaran tunjangan sertifikasi guru, pembayaran tunjangan fungsional guru dan pelayanan NUPTK guru tidak dilakukan secara rutin, karena dukungan dari Kepala Kantor Kementerian Agama Kota Jambi kurang memberi dukungan baik dukungan moril maupun materil. Disamping itu Kepala Kantor Kementerian Agama Kota Jambi tidak melihat kondisi yang dialami pegawai dan sumber daya pegawai yang dimiliki. Seharusnya pihak kantor melibatkan para pegawai dan guru pembimbing, namun kenyataannya Kepala Kantor Kementerian Agama Kota Jambi hanya melibatkan wakil kurikulum, kepegawaian, prasarana dan kepala TU. Ketidakoptimal yang lain dalam perencanaan kegiatan ekstrakurikuler di bidang keagamaan dalam pemberdayaan budaya kantor di Kantor Kementerian Agama Kota Jambi seperti pelayanan terhadap tenaga pendidik dan kependidikan meliputi pembayaran tunjangan sertifikasi guru, pembayaran tunjangan fungsional guru dan pelayanan NUPTK guru adalah tidak mengikuti kalender pendidikan yang tersedia.

Sedangkan pelaksanaan Kepala Kantor Kementerian Agama Kota Jambi dalam meningkatkan pelayanan publik di bidang Pendidikan Agama Islam meliputi pelayanan terhadap tenaga pendidik dan kependidikan meliputi pembayaran tunjangan sertifikasi guru, pembayaran tunjangan fungsional guru dan pelayanan NUPTK guru dapat meningkatkan kebiasaan pegawai menyelesaikan tugasnya tepat waktu. Kantor sebagai lembaga pemerintah yang melayani guru dinilai memiliki kelebihan dibandingkan lembaga perkantoran lainnya, di Kantor Kementerian Agama Kota Jambi secara spesifik membentuk akhlak dan moral pegawai dalam melayani guru. Untuk mempercepat peningkatan melaksanakan kegiatan Kepala Kantor Kementerian Agama Kota Jambi dalam meningkatkan pelayanan publik di bidang Pendidikan Agama Islam dapat meningkatkan kebiasaan pegawai melayani guru tepat waktu, hal ini diperlukan pemahaman pegawai terhadap hakekat dan problematika tugasnya di kantor. Atas dasar itu apabila pegawai mendapatkan sentuhan menajemen dan kepemimpinan yang baik niscaya akan dengan mudah menjadi pegawai kantor yang dikagumi masyarakat. Seandainya mutu pelayanan publik di kantor itu sejajar saja dengan kantor lain, niscaya akan dipilih masyarakat sebagai lembaga pemerintah yang terbaik, apalagi kalau lebih baik. Adapun budaya pegawai Kantor Kementerian Agama Kota Jambi yang masih bertahan adalah sebelum melaksanakan tugasnya di kantor terlebih dahulu selalu memberikan pelayanan terhadap tenaga pendidik dan kependidikan meliputi pembayaran tunjangan sertifikasi guru, pembayaran tunjangan fungsional

41 Riyan Hidayat, Aparatur Sipil Negara Dalam Pelayanan Publik, http://sumsel1. kemenag.go.id/index.php?a=artikel\&id=259. Diakses Tanggal 24 Desember 2016. 
guru dan pelayanan NUPTK guru bersikap sopan santun dan mempermudahkan urusan sesuai dengan aturan yang berlaku.

Kepala Kantor Kementerian Agama Kota Jambi belum melakukan berbagai upaya melakukan pengawasan pembinaan pelayanan publik yang dilakukan oleh pegawai yang meliputi pembayaran tunjangan sertifikasi guru, pembayaran tunjangan fungsional guru dan pelayanan NUPTK guru, sehingga Kepala Kantor Kementerian Agama Kota Jambi mengalami kesulitan melakukan pengawasan, hal ini disebabkan kepala tidak menguasai indikator keberhasilan pegawai dalam melaksanakan tugasnya dalam meningkatkan pelayanan publik di bidang Pendidikan Agama Islam. Di samping itu Kepala Kantor Kementerian Agama Kota Jambi tidak melibatkan pihak lain seperti Kasubbag Tata Usaha dan Kepala Seksi, dan pegawai lainnya yang profesional melakukan pengawasan terhadap berhasil atau tidaknya berrbagai tugas yang dilaksanakan pegawai pada seksi pendidikan dan madrasah di Kantor Kementerian Agama Kota Jambi dalam meningkatkan pelayanan publik di bidang Pendidikan Agama Islam yang telah dilaksanakan. Bila dilihat dari fakta yang ada masih terdapat pegawai yang melaksanakan tugasnya dalam melayani publik dalam hal ini mengenai pelayanan pembayaran tunjangan sertifikasi guru, pembayaran tunjangan fungsional guru dan pelayanan NUPTK guru tidak sesuai dengan SOP sehingga mengecewakan guru dan masyarakat yang berurusan di kantor tersebut.

\section{Penutup}

Kegiatan pada seksi Pendidikan Madrasah seperti pelayanan terhadap tenaga pendidik dan kependidikan meliputi pembayaran tunjangan sertifikasi guru, pembayaran tunjangan fungsional guru dan pelayanan NUPTK guru dapat dikembangkan dalam beragam cara. Penyelenggaraan kegiatan yang memberikan kesempatan luas kepada pihak kantor, pada gilirannya menuntut pimpinan kantor, pegawai, dan pihak-pihak yang berkepentingan lainnya untuk secara kreatif merancang sejumlah kegiatan sebagai muatan kegiatan pada seksi pendidikan madrasah. Manajemen Kepala Kantor Kementerian Agama Kota Jambi dalam meningkatkan pelayanan publik di bidang Pendidikan Agama Islam meliputi pelayanan terhadap tenaga pendidik dan kependidikan meliputi pembayaran tunjangan sertifikasi guru, pembayaran tunjangan fungsional guru dan pelayanan NUPTK guru dapat meningkatkan kebiasaan pegawai untuk melaksanakan tugas dengan tepat waktunya. Disamping itu Kepala Kantor Kementerian Agama Kota Jambi selalu yang mengacu kepada menjaga karakteristik dan ciri keunggulan kantor yang kompetitif antara lain: 1) pegawai di kantor menempatkan nilai-nilai agama dan budaya luhur bangsa sebagai spirit dalam melaksanakan tugas pada seksi pendidikan madrasah; 2) pegawai di kantor mempertahankan budaya kantor berdasarkan prinsip-prinsip pelayanan yang khusus. 
Pelayanan khusus di kantor antara lain (a) holistik, pemberdayaan budaya kerja pegawai pada aspek jasmani dan rohani secara utuh, pemberdayaan budaya kerja pegawai memiliki aspek cipta, rasa, karsa dan karya yang Islami; (b) sinergi antara tugas, akidah, ibadah, muamalah dan akhlakul karimah;(c) memiliki interkoneksitas pegawai ilmu agama dan IPTEKS (ilmu pengetahuan, teknologi dan seni); (d) berkelanjutan dalam konteks hubungan antara tradisi dengan modernitas, dan (e) akomodatif antara kearifan lokal dan perkembangan global. 3) pegawai kantor menjunjung tinggi nilai-nilai kejujuran, keadilan, kesetaraan, dan demokrasi dalam melayani guru yang berurusan sesuai dengan Standar Operasi Pelaksanaan.

\section{Bibliografi}

Al Imam Al-Hafiz Abi Abdullah Muhammad Bin Ismail Al-Bukhori, Sohih AlBukhari. Kairo: MussasahAl-Mukhtar, 2007.

Ali Al Jumbulati, Abdul Futuh At Tuwaanisi, Perbandingan Pendidikan Islam, terj. M. Arifin, Dirasatun Muqaaranatun fit-Tarbiyyatil Islamiyyah,. Jakarta: Rineka Cipta, 2008.

Alim, Yusuf Hamid, Al-Maqashid Al-Ammah fi As-Syari'ah Al-Islamiah. Riyadh: AlDar Alllmiah Al-Kitab Al-Islami, 2009.

Akh. Muzakki, Kholilah, Ilmi Pendidikan Islam. Surabaya: Kopertais IV Press, 2006.

Azis, Rosmiaty, Rekontruksi Pendidikan Islam dalam Era Post-Modernisme Tantangan Menuju Civil Society di Indonesia, Tesis. Makasar: IAIN Alaudin, 2010.

Azra, Azyumardi, Pendidikan Islam: Tradisi dn Modernisasi di Tengah Tantangan Milenium III. Jakarta: Kencana Prenada Media Group, 2012.

Bafadal, Ibrahim, Manajemen Perlengkapan Sekolah. Jakarta: Bumi Aksara, 2008.

Bateman, Thomas S. dan Snell, Scott A, Management: The New Competitive Landscape. Sixth Edition. New York: McGraw Hill, 2008.

Daulay, Haidar Putra, Pendidikan Islam: dalam Sistem Pendidikan Nasional di Indonesia. Jakarta: Kencana, 2008.

Djumransjah, M, Pengantar Filsafat Pendidikan. Malang: Bayumedia, 2009.

Dokumen Kantor Kementerian Agama Kota Jambi Tahun 2016.

Dokumen Kantor Kementerian Agama Kota Jambi Pada Tanggal 10 Maret 2016.

EM Zul Fajri, Ratu Aprilia Senja, Kamus Lengkap Bahasa Indonesia. tt.: Difa Publisher, 2008.

Engkoswara, Dasar-dasar Administrasi Pendidikan. Jakarta: Dirjen Dikti, Depdikbud, 2008. 
Kotler, Philip, Manajemen Pemasaran, Analisis, Perencanaan, Implementasi, dan Pengendalian (terj. Supranto), Printice Hall, edisi Indonesia, Jakarta, 1994.

Nanang, Fattah, Landasan Manajemen Pendidikan. Bandung: Remaja Rosdakarya, 2006.

R, Terry Goerge, Prinsip-Prinsip Manajemen. Alih bahasa Smith, J. Jakarta: Bumi Aksra, 2009.

Roqib, Moh., Ilmu Pendidikan Islam: Pengembangan Pendidikan Integratif di Sekolah, Keluarga dan Masyarakat. Yogyakarta: Lkis Group, 2011.

Siagian, Sondang P., Fungsi-Fungsi Manajerial. Jakarta: Bumi Aksara. 2008.

Sugiyanto, "Mengukur Kinerja Kebijakan Publik (Pertanyaan Korelasional Terhadap Aktualisasi Good Governance)", dalam Jurnal Good Governance, Vol 3, No.1, Mei 2006, Program Magister STIA-LAN, Jakarta.

Sule, Tisnawati, Ernie dan Seafullah Kurniawan, Pengantar Manajemen. Jakarta: Kencana, 2008.

Sutedi, Adrian, Hukum Perizinan Dalam Sektor Pelayanan Publik, Jakarta: Sinar Grafika, 2010. 